\title{
Kajian Struktur Pita Elektronik Graphene dan Graphane Menggunakan Model Ikatan Kuat Realistik dengan Ketakteraturan
}

\author{
Muhammad Qosim*, Iman Santoso** \\ Jurusan Fisika, Fakultas Matematika dan Ilmu Pengetahuan Alam, \\ Universitas Gadjah Mada, Yogyakarta 55281, Indonesia \\ * Email: qosim.muh@mail.ugm.ac.id \\ **Email: iman.santoso@ugm.ac.id
}

\begin{abstract}
Abstrak - Dua model matriks hasil modifikasi model ikatan kuat untuk mendekati struktur pita elektronik graphene dan graphane dengan banyak atom beserta beberapa macam ketakteraturannya telah berhasil disusun. Model total menjumlahkan matriks tansfer dan overlap tiap unit cell berukuran $2 \times 2$ elemen untuk graphene dan $4 \times 4$ elemen untuk graphane. Model diagonal menyusun tiap unit cell secara diagonal pada matriks transfer dan overlapnya dengan ukuran $2 N \times 2 N$ elemen untuk graphene dan $4 N \times 4 N$ elemen untuk graphane $(N=$ jumlah unit cell).Model-model matriks tersebut kemudian didiagonalisasi secara numerik untuk dihasilkan grafik dispersi energi dan rapat keadaan. Pengkajian lebih lanjut tentang ketakteraturan diawali dengan simetrisasi rapat keadaan yaitu membuang matriks overlap s dan mereduksi nilai parameter hopping menjadi $1 \mathrm{eV}$. Variasi parameter hopping next nearest neighbour t' hanya mengubah rentang pita energi dan menggeser titik K paralel dengan sumbu momentum.
\end{abstract}

Kata kunci:graphene, graphane, model ikatan kuat, dispersi energi, rapat keadaan,

Abstract - Two matrix models as a result of tight binding model modification toapproach electronic band structure of graphene and graphane with its disorder has been constructed.Total model add up transfer and overlap matrices for every unit cell with $2 \times 2$ element size in graphene and $4 \times 4$ element for graphane. Diagonal model arrange every unit cell diagonally in transfer and overlap matrices with $2 \mathrm{~N} \times 2 \mathrm{~N}$ element size for graphene and $4 \mathrm{~N} \times 4 \mathrm{~N}$ element for graphane $(N=$ total unit cell). Those matrix models then diagonalized numerically to get energy dispersion relation and density of states. Further studies about disorder starts with density of states symmetrization that is vanishing overlap matrix s and reduces hopping parameter to $1 \mathrm{eV}$. Next nearest neighbour hopping parameter t' variations only change energy band range and stretch $K$ point parallel with the momentum axis.

Key words: graphene, graphane, tight binding model, energy dispersion, density of states

\section{PENDAHULUAN}

Graphene merupakan material dasar dua dimensi berbentuk saranglebah sebagai penyusun berbagai alotrop karbon. Dalam tiga dimensi tumpukan graphene yang disatukan oleh ikatan Van der Waal disebut grafit. Tabung nano karbon adalah graphene dalam bentuk satu dimensi, sedangkanbuckyball atau fullerene adalah graphene dalam dimensi nol [1].Semua sifat - sifat elektronik, optik, termal, juga magnetik, yang menjadi kelebihan graphene dapat digambarkan dengan jelas dengan mengkajinya mulai dari ranah fundamental yaitu struktur pita elektronik (energidispersi) juga rapat keadaan material graphene. Graphene yang memilikisifat semimetal (pita valensi dan konduksi bertemu pada titik $\mathrm{K}$ yang simetri) dapat dimodifikasi struktur pitanya sehingga terjadi celah di antara pitakonduksi dan valensinya entah di atas atau di bawah aras Fermi. Berbagaimodel telah dicoba untuk menggambarkan struktur pita elektronik graphenebaik secara analitik [2],[3], yangmenggunakan model ikatan kuat, maupun numerik seperti Density Functional Theory [4], aproksimasi GW [5],juga Tight Binding dengan penyelesaian TDSE [6].

Penelitian ini akan diarahkan pada penyelidikan dispersi energi danrapat keadaan dari graphene murni dan dengan beberapa macam ketakteraturan, serta graphane murni juga dengan ketakteraturannya. Graphene yangtidak memiliki celah dalam pita energinya, memerlukan pengotor ataupunketakteraturan lain sehingga dapat dipakai sebagai material semikonduktor.Beberapa material yang dapat menjadi pengotor diantaranya hidrogen, silikon, dan beberapa molekul organik seperti $\mathrm{CH}_{3}, \mathrm{C}_{2} \mathrm{H}_{5}, \mathrm{CH}_{2} \mathrm{OH}$, dan beberapa grup $\mathrm{H}$ dan $\mathrm{OH}$ lainnya. Sedang ketakteraturan dapat dihasilkan dari perubahan lokal acak atas potensial on-site dan renormalisasi acak dari parameter hopping pada model ikatan kuat. Digunakan model ikatan kuat yang telahdimodifikasi untuk banyak atom pada penelitian ini sehingga dapat menggambarkan struktur pita lebih mirip dengan hasil eksperimen.

\section{LANDASAN TEORI}

Ada beberapa model untuk menjelaskan struktur pita energi dari suatu material elektronik, dari model dasar seperti Nearly Free Electron Model, Linear Combination of Atomic Orbital, Tight Binding Model sampai dengan modelrumit untuk banyak atom seperti Hubbard Model, dan Density Functional Theory. Tight Binding Model atau Model Ikatan Kuat mencoba mendekati struktur pita elektronik suatu material menggunakan himpunan fungsi gelombangyang berdasar 
pada superposisi fungsi gelombang untuk atom terisolasi yangterdapat pada tiap posisi atom di dalam kristal.Jika atom diletakkan pada sebuah kristal, fungsi gelombang atom yang berdekatan salingtumpang tindih (overlap). Ketumpangtindihannya akan sangat berkurang jika elektronnya terikat sangat kuat pada inti. Dari sinilah mengapa model inidisebut Model Ikatan Kuat.

Penyelesaian untuk persamaan Schrodinger gayut waktu satu elektrondidekati dengan $\phi\left(\boldsymbol{r}-\boldsymbol{R}_{j, i}\right)$ dari model Linear Combination of Atomic Orbital kemudian disusun pada sebuah fungsi Bloch yang bergantung pada vektor posisi $\boldsymbol{r}$ dan vektor gelombang $\boldsymbol{k}$ berikut

$$
\Phi_{j}(\mathbf{k}, \mathbf{r})=\frac{1}{\sqrt{N}} \sum_{i=1}^{N} e^{i \mathbf{k} \mathbf{R}_{j, i}} \phi\left(\mathbf{r}-\mathbf{R}_{j, i}\right)
$$

dengan $i=1, \ldots, N$ banyaknya unit cell dan $j=1, \ldots, n$ banyaknya orbitalatom yang dalam hal ini karena tiap unit cell terdiri dari 2 atom maka $j=A, B . \quad \boldsymbol{R} j, i$ menunjukkan orbital ke-j pada unitcell ke- $i$.

Graphene monolayer memiliki dua atom per unit cell dengan label $j=A$ dan $j=B$, lalu pada penelitian ini hanya diambil satu orbital paling atastiap atom yaitu orbital $2 \mathrm{p}_{\mathrm{z}}$ karena orbital tersebutlah yang paling menentukansifat elektronik graphene. Dengan mensubstitusi ekspresi fungsi Bloch kedalam definisi integral transfer dan overlap diperoleh matriks integral transfer dan overlap untuk graphene dengan 2 atom perunit cell

$$
\begin{gathered}
H=\left(\begin{array}{cc}
\epsilon_{2 p} & -t f(k) \\
-t f^{*}(k) & \epsilon_{2 p}
\end{array}\right) \\
S=\left(\begin{array}{cc}
1 & s f(k) \\
s f^{*}(k) & 1
\end{array}\right)
\end{gathered}
$$

dengan $H$ adalah matriks transfer, $S$ matriks overlap, sedangkan

$$
f(k)=e^{i k_{y f} a / \sqrt{3}}+e^{i k_{x} a / 2} \mathrm{e}^{-i k_{y} a / 2 \sqrt{3}}+e^{-i k_{m} a / 2} e^{-i k_{y} a / 2 \sqrt{3}}
$$

merupakan fungsi yang memerantarai ikatan nearest neighbour.

Kedua matriks kemudian dimasukkan ke dalam persamaan eigen nilai dan dicari determinan

$$
\operatorname{det}\left(\begin{array}{cc}
\epsilon_{2 p}-E & -(t+E s) f(k) \\
-(t+E s) f^{*}(k) & \epsilon_{2 p}-E
\end{array}\right)=0
$$

sehingga diperoleh

$$
E_{ \pm}=\frac{\epsilon_{2 p} \pm t|f(\mathbf{k})|}{1 \mp s|f(\mathbf{k})|}
$$

Dengan parameter lompatan nearest neighbourt $=3,033$, $s=0,129$, dan nilai $\epsilon_{2 p}=0$ yang merupakan besar energiuntuk orbital $2 \mathrm{p}_{z}[2]$.

\section{METODE PENELITIAN}

Ada dua model yang berhasil dibuat untuk memodelkan graphene dan graphane dengan ketakteraturannya masing-masing. Model pertama dan kedua dibedakan oleh dua hal, fungsi cobanya dan bentuk matriks hamiltonannya. Model pertama (yang selanjutnya akan disebut model total) akan menjumlahkan hamiltonan untuk semua unit cell sehingga ada faktor $1 / \sqrt{ } \mathrm{N}$ pada fungsi cobanya seperti dalam pers.1, sedangkan model kedua (yang selanjutnya akan disebut model diagonal) akan menyediki perbedaan bentuk pita energi satu unit cell dengan unit cell lain maka faktor $1 / \sqrt{ } \mathrm{N}$ pada fungsi coba dihilangkan.

\section{Graphene dan Graphane Model Total}

Bentuk matriks hamiltonan pada model total hampir sama dengan bentuk matriks yang disajikan oleh Ref. [2], hanya saja karena model ini akan memvariasikan nearest neighbor hopping parameter $t_{i}$ dan potensial onsite $v_{i}$-nya maka matriks dengan elemen $2 \times 2$ untuk graphene dan 4 $\times 4$ untuk graphane akan dijumlahkan berjejer sebanyak unit cell yang dilibatkan dalam perhitungan dengan variasi acak di setiap unit cell.

Bentuk hamiltonan untuk graphene model total adalah sebagai berikut

$$
H_{\text {greT }}=H_{\text {marni }}+H_{\text {next }}+H_{\text {onsite }}+H_{\text {hopp }}
$$

Berbeda dengan Ref. [2], model ini memasukkan faktor next nearest neigbour pada suku kedua, suku pertama menunjukkan hamiltonan graphene murni, variasi nilai atau ketakteraturan akan dimasukkan pada suku ketiga dan keempat yaitu pada hamiltonan on-site dan hopping parameter yang terletak pada $H_{\text {hopp }}$.

$$
H_{m u m i}=\sum_{i=1}^{N} H_{m u r^{m}, i}
$$

Setiap suku merupakan penjumlahan dari hamiltonan tiap unit cell dengan hamiltonan unit cell satu berbeda dengan unit cell lain. Seperti suku pertama $H_{\text {greт }}$ yang diungkapkan dalam persamaan (7), dengan

$$
H_{m u r n i, i}=\left(\begin{array}{cc}
\frac{\epsilon_{2 p}}{N} & -\frac{t}{N} f(k) \\
-\frac{t^{*}}{N} f^{*}(k) & \frac{C_{2 p}}{N}
\end{array}\right)
$$

Suku kedua $H_{\text {next }}$ adalah representasi dari interaksi next nearest neighbour. Bentuk matriksnya mirip dengan matriks $H_{\text {murni }}$ hanya saja bagian diagonalnya nol, dan fungsi $f(k)$ diganti dengan fungsi next nearest neighbour

$$
\begin{aligned}
g(k) & =e^{i k_{x}-a / 2} e^{i k_{y} a \sqrt{3} / 2}+e^{i k_{x} a / 2} e^{i k_{y} a \sqrt{3} / 2}+e^{i k_{x} a}(9) \\
& +e^{i k_{x} a / 2} e^{i k_{y i}-a \sqrt{3} / 2}+e^{i k_{* x}-a / 2} e^{i k_{y}-a \sqrt{3} / 2}+e^{i k_{x x}-a}
\end{aligned}
$$


Ketakteraturan on-site dan nearest neighbour hopping mulai diberikan pada suku ketiga, $H_{\text {onsite }}$, dan $H_{\text {hopp }}$. Kedua suku hamiltonan tersebut mengganggu bagian diagonal dan off-diagonal matriks $H_{\text {murni }}$ dengan nilai acak. $H_{\text {onsite }}$ berperan untuk memberikan nilai acak pada bagian diagonal matriks $H_{\text {murni }}$ dengan potensial acak $v_{i}$ yang didistribusikan secara merata dengan nilai acak mulai dari $-v_{r}$ sampai dengan $+v_{r}$. Demikian halnya $H_{\text {hopp }}$ yang memberikan nilai acak bagian off-diagonal dengan menambahkan nilai acak mulai dari $-t_{r}$ sampai dengan $+t_{r}$ pada parameter hopping $t$.

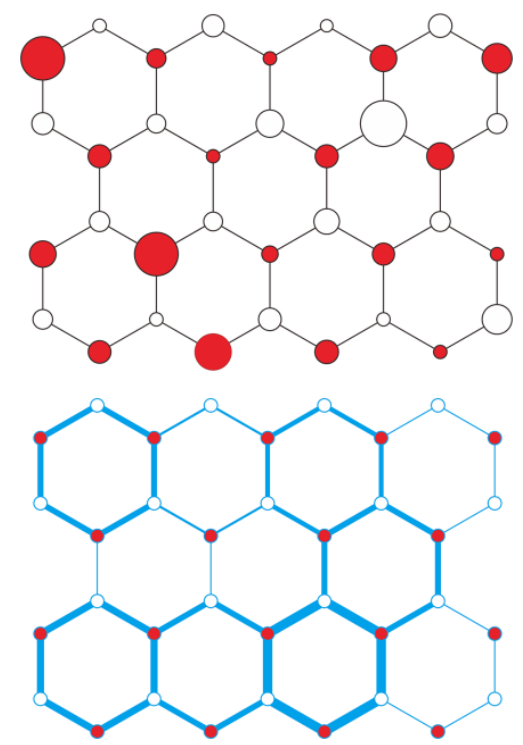

Gambar 1. Ilustrasi ketakteraturan potensial on-site $v_{r}$ (atas) dan parameter hopping $t_{r}$ (bawah) struktur ruang real graphene.

Ketakteraturan yang pertama merupakan wujud dari pergeseran lokalpotensial kimia dari fermion Dirac yaitu menggeser titik Dirac secara lokal(gambar 1. atas). Sedangkan renormalisasi acak dari hopping $t_{i}$ memiliki kaitan fisis dengan perubahan jarak, atau tebal di antara lengan orbital(gambar 1. bawah) $p_{z}$ [6].

Bentuk matriks hamiltonan untuk graphane modeltotal hampir sama dengan graphene yang telah dijabarkan di atas, hanya sajagraphane memiliki $4 \times 4$ elemen matriks untuk setiap unit cell. Hamiltonan totalnya adalah

$$
H_{g \mathrm{raT}}=\sum_{i=1}^{N} H_{g r a T, i}
$$

dengan

$$
H_{g r a T, *}=\left(\begin{array}{cccc}
\frac{\epsilon_{2}}{N} & \frac{V m_{i}}{N} & -\frac{t}{N} f(k) & 0 \\
\frac{V m_{i}}{N} & \frac{\epsilon m_{d i}}{N} & 0 & 0 \\
-\frac{t}{N} f^{*}(k) & 0 & \frac{\epsilon_{p j}}{N} & \frac{V m_{i}}{N} \\
0 & 0 & \frac{V m_{i}}{N} & \frac{\epsilon m_{d i}}{N}
\end{array}\right)
$$

$V_{m i}$ merupakan parameter lompatan antara atom hidrogen dan karbon padaunit cell $i$ dan $\epsilon_{m d i}$ adalah potensial on-site untuk atom hidrogen pada unit cell $i$, keduanya jika atom karbon pada unit cell tersebut tidak berikatan denganhidrogen atau tidak dikotori. Sedang jika dengan pengotor, nilai $V_{m i}$ berubah dari $0,2 \mathrm{t}$ menjadi $2 \mathrm{t}$ sedangkan $\epsilon_{m d i}$ berubah dari $-t / 166$ menjadi $-t / 16$.

\section{Graphene dan Graphane Model Diagonal}

Model kedua menyusun unit cell - unit cell yang berisi dua atau empatatom secara berurutan sebagai komponen baris dan kolom. Dihasilkan matriks yang hanya komponen diagonalnya yang tidak nol. Graphene murnimemiliki dua atom untuk setiap unit cell, jadi matriks setiap unit cell mempunyai $2 \times 2$ elemen, sedangkan graphane murni memiliki empat atom untuksetiap unit cell, dua atom hidrogen dan dua atom karbon, jadi ada $4 \times 4$ elementiap unit cell. Graphene akan memiliki $2 \mathrm{~N} \times 2 \mathrm{~N}$ elemen matriks, sedangkangraphane akan memiliki $4 \mathrm{~N} \times 4 \mathrm{~N}$ elemen matriks dengan $\mathrm{N}$ adalah banyakatom. Bentuk matriks hamiltonan untuk graphene model diagonal adalah

$$
H_{g r e D}=\left(\begin{array}{ccccccc}
\epsilon_{2 p} & -t f(k) & 0 & \cdots & \cdots & \cdots & 0 \\
-t f^{*}(k) & \epsilon_{2 p} & 0 & \ldots & \cdots & \cdots & 0 \\
0 & 0 & \epsilon_{2 p} & -t f(k) & 0 & \cdots & 0 \\
0 & 0 & -t f^{*}(k) & \epsilon_{2 p} & 0 & \cdots & 0 \\
0 & 0 & 0 & 0 & \ddots & \ldots & 0 \\
\vdots & \vdots & \vdots & \vdots & \vdots & \vdots & \vdots \\
0 & 0 & 0 & \ldots & 0 & \epsilon_{2 p} & -t f(k) \\
0 & 0 & 0 & \cdots & 0 & -i f^{*}(k) & \epsilon_{2 p}
\end{array}\right)
$$


sedang untuk graphanemodel diagonal

$$
H_{g r a D}=\left(\begin{array}{ccccccc}
\epsilon_{2 p} & V m_{1} & -t f(k) & 0 & 0 & \ldots & 0 \\
V m_{1} & \epsilon m_{d 1} & 0 & 0 & 0 & \cdots & 0 \\
-t f^{*}(k) & 0 & \epsilon_{2 p} & V m_{1} & 0 & \ldots & 0 \\
0 & 0 & V m_{1} & \epsilon m_{d 1} & 0 & \ldots & 0 \\
0 & 0 & 0 & 0 & \ddots & \ldots & 0 \\
\vdots & \vdots & \vdots & \vdots & \vdots & \ddots & \vdots \\
0 & \cdots & 0 & \epsilon_{2 p} & V m_{N} & -t f(k) & 0 \\
0 & \cdots & 0 & V m_{N} & \epsilon m_{d N} & 0 & 0 \\
0 & \cdots & 0 & -t f^{*}(k) & 0 & \epsilon m_{p} & V m_{N} \\
0 & \cdots & 0 & 0 & 0 & V m_{N} & \epsilon m_{d N}
\end{array}\right)
$$

\section{Proses Diagonalisasi Numerik}

Proses diagonalisasi numerikdiawali dengan menentukan beberapa input variasi seperti unit cell $(\mathrm{N})$, banyak elemenmatriks $(\mathrm{J})$ dengan $\mathrm{J}=2 \mathrm{~N}$ untuk graphene dan $\mathrm{J}=4 \mathrm{~N}$ untuk graphane model kedua, model pertama tidak mengulang unit cell jadi graphene memilikidua elemen sedang graphane empat elemen matriks.

Langkah selanjutnya membuat matriks grid vektor dua dimensi dengan komponen $\boldsymbol{k}_{\boldsymbol{x}}$ dan $\boldsymbol{k}_{\boldsymbol{y}}$ rentang masingmasing antara $-2,8$ s.d. 2,8 untukdimasukkan ke dalam perhitungan selanjutnya sebagai parameter momentum dalam fungsi $f\left(\boldsymbol{k}_{x}, \boldsymbol{k}_{y}\right)$ dan $g\left(\boldsymbol{k}_{x}, \boldsymbol{k}_{\boldsymbol{y}}\right)$, juga membuat matriks berelemennol tiga dimensi dengan banyak elemen baris dan kolomnya sama denganbanyaknya elemen momentum dan tingginya sama dengan J. Kemudianmemasukkan inputan variasi yang telah ditentukan pada langkah pertamake dalam matriks overlap dan matriks transfer sesuai dengan model graphene dan graphane terkait. Matriks yang telah terisi dengan nilai-nilai tertentukemudian didiagonalisasi secara numerik untuk mendapatkan nilai energieigen dan memasukkannya ke dalam matriks nol tiga dimensi yang telah disebutkan dalam langkah kedua. Matriks tersebut dapat diplot untuk mendapatkan grafik dispersi energi. Grafik dispersi energi untuk model pertamaakan terlihat sebagai tumpukan bidang-bidang dua dimensi dengan banyaktumpukan sama dengan banyak $\mathrm{J}$.

Rapat keadaan dapat diperoleh dengan menghitung banyaknya titik-titikpada semua permukaan energi untuk setiap rentang energi. Titik-titik tersebut dianggap sebagai state yang dihuni dalam ruang kisi balik graphene.

\section{HASIL DAN PEMBAHASAN}

Perhitungan diawali dengan melihat kaitan antara pelibatan matriks overlap $s$, besar parameter nearest neighbourt, juga pengikutsertaan parameter next nearest neighbour $t$ ' dengan hasil grafik yang diperoleh. Nilai $t$ =3,033 eV merujuk pada Ref. [2] dengan mengikutkan matriks overlap $s$ menghasilkan pita valensi dan konduksi

yang tidak simetris dan keduanya masih bersentuhan pada aras Fermi di titik nol seperti yang diperlihatkan gambar 2.a. (pita merah). Gambar 2.b. memperlihatkan rapat keadaan pita valensi lebih besar walau memiliki rentang yang lebih pendek dari pada pita konduksi.

Selanjutnya matriks overlap $s$ disingkirkan dari proses diagonalisasi numerik sehingga diperoleh pita hole dan elektron yang simetris dengan rentang energi kurang lebih -9 s.d. 9 eV (pita biru). Simetri tidak terlihat pada rapat keadaannya dengan pita valensi lebih rapat dari pita konduksinya. Sedangkan pembuangan matriks overlap dan pereduksian nilai t menjadi $1 \mathrm{eV}$ menghasilkan pita energi dan rapat keadaan yang simetris (gambar 2.d). Muncul semacam celah rapat keadaan di antara singularitas van Hove setelah melalui pereduksian ini. Proses pereduksian nilai $\mathrm{t}$ ini menguntungkan dalam perbandingan data hasil eksperimen Angle Resolved Photo-Emission Spectroscopy (ARPES) yang biasa diperoleh dengan energi rendah. Pembuangan matriks overlap dan pereduksian parameter $t$ menjadi $1 \mathrm{eV}$ mengurangi titik puncak masing-masing pita dari $9 \mathrm{eV}$ menjadi hanya $3 \mathrm{eV}$.

Hasil yang diperoleh dari modifikasi parameter next nearest neighbour $t$ '(gambar 3) berbeda dengan Ref. [7] yang memecah simetri rapat keadaan elektron-hole. Pemodelan ini menarik keempat titik Dirac saling mendekat pada sumbu momentum dan memperbesar rentang energi jika nilai $t$ ' diperbesar, namun tidak merusak simetri pita maupun rapat keadaannya. Ada semacam penurunan rapat keadaan yang drastis di area puncak bawah pita valensi dan puncak atas pita konduksi pada variasi next nearest neighbour $t^{\prime}=0,1 t$. Tinggi singularitas van Hove tidak terkait dengan besar nilai parameter $t$ '-nya.

Seperti yang dilakukan Ref. [7] dan Ref. [8], proses simetrisasi pita energi pada grafik dispersi energi dan rapat keadaan dengan membuang matriks overlap, mereduksi nilai $t$, dan menyingkirkan parameter next nearest neighbourt' diharapkan dapat memudahkan dalam menganalisis perubahan-perubahan yang ditimbulkan akibat pemberian ketakteraturan acak pada parameter-parameter pokok seperti potensial on-site $v_{r}$ dan parameter nearest neighbour hoppingt ${ }_{r}$. 

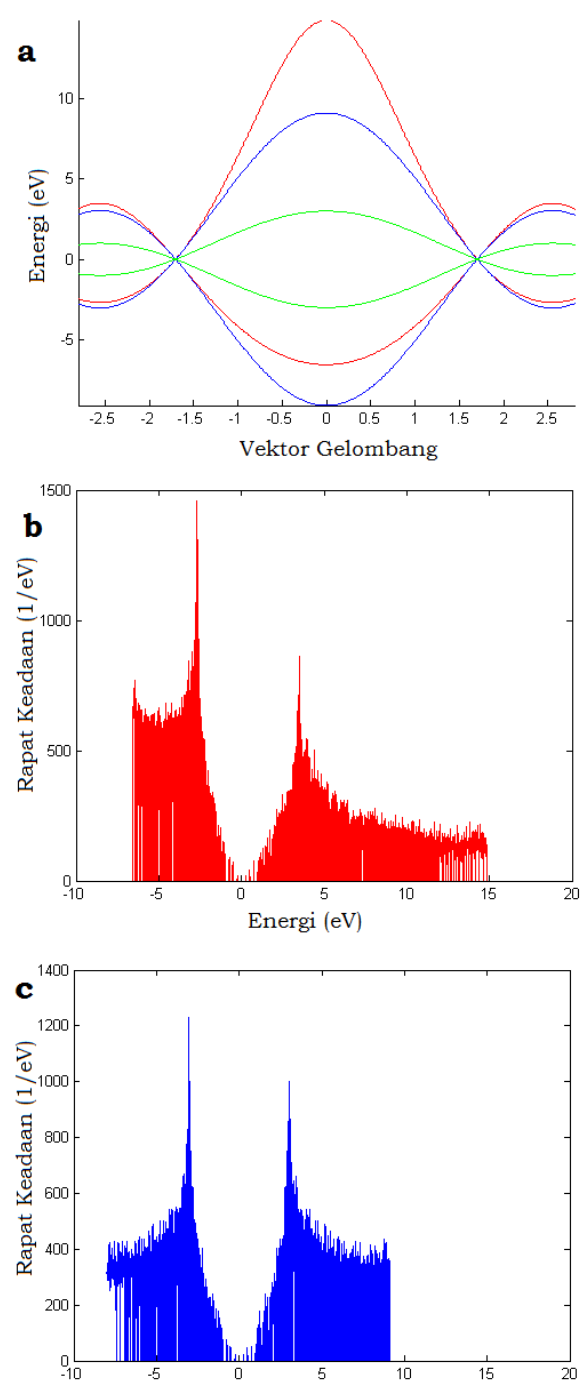

Energi (eV)

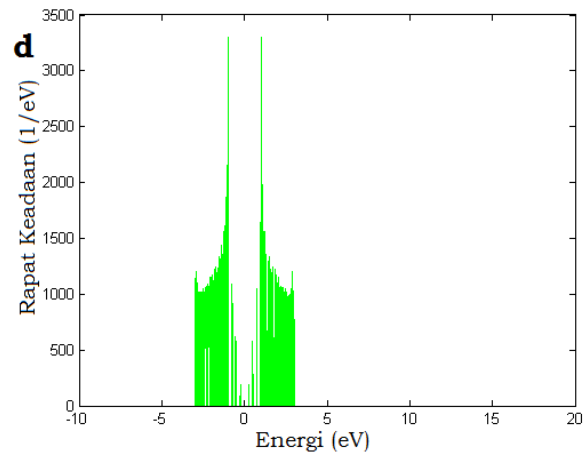

Gambar 2. (a). Grafik dispersi energi untuk tiga tipe pita. Grafik rapat keadaan (b). graphene dengan $t=$ $3,033 \mathrm{eV}$ danmelibatkan matriks overlap $s$, (c). dengan $t=3,033 \mathrm{eV}$ tanpa s (d). $t=1 \mathrm{eV}$ tanpa $s$.

\section{KESIMPULAN}

Karakteristik graphene dapat dikaji melalui sebuah pendekatan model ikatan kuat. Analisis yang lebih realistik dapat dilakukan dengan melibatkan banyak atom beserta ketakteraturannya. Model ikatan kuat perlu dimodifikasi sehingga dapat menampung banyak atom tersebut.Telah berhasil disusun dua model ikatan kuat yang dimodifikasi untukbanyak atom masing-masing untuk graphene dan graphane. Model totalmenjumlahkan matriks tansfer dan overlap tiap unit cell kemudian mendiagonalisasinya secara numerik. Model diagonal menyusun tiap unit cell secara diagonal pada matriks transfer dan overlapnyalalu mendiagonalisasinya secaranumerik untuk dihasilkan grafik dispersi energi dan rapat keadaan.

\section{PUSTAKA}

\section{Artikel jurnal:}

[1] M. S. Fuhrer, Chun Ning Lau, MacDonald Alan H, Graphene: Materially Better Carbon, MRS Bulletin. Vol $35,2010$.

[2] E. McCann, Electronic properties of monolayer and bilayer graphene,arXiv:1205.4849v1, 2012.

[3] A. H. Castro Neto, F. Guinea, N. M. R. Peres, K. S. Novoselov dan A. K.Geim, The electronic properties of graphene, REVIEWS OF MODERNPHYSICS, VOLUME 81, JANUARY-MARCH 2009

[4] P. Chandrachud, Bhalchandra S. Pujari, and D. G. Kanhere, Fromgraphene to graphane : A density functional investigation of metal insulator transition, arXiv:0911.1505v1. 2010.

[5] P. Cudazzo, Claudio Attaccalite, Ilya V. Tokatly,and Angel Rubio, Strong Charge-Transfer Excitonic Effects and the Bose-Einstein Exciton Condensate in Graphane, PHYSICAL REVIEW LETTERS: PRL104,226804, 2010.

[6] S. Yuan, Rafael Roldan, Hans De Raedt, and Mikhail I. Katsnelson, Optical conductivity of disordered graphene beyond the Dirac cone approximation, PHYSICAL REVIEW B84, 195418, 2011.

[7] V. M. Pereira, J. M. B. Lopes dos Santos., A. H. Castro Neto, Modeling Disorder in Graphene, PHYSICAL REVIEW B77, 115109, 2008. 

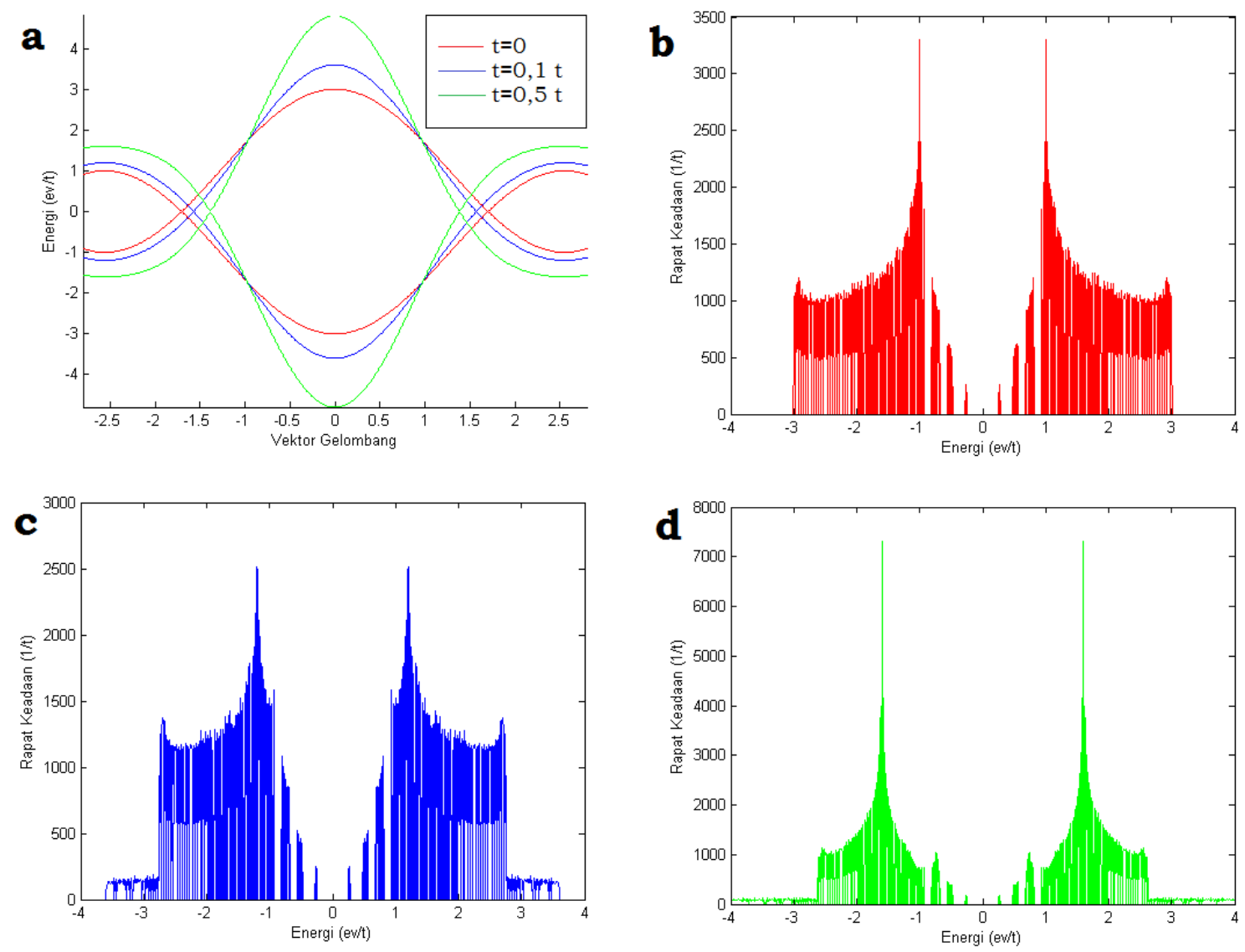

Gambar 3. (a). Grafik dispersi energi untuk tiga tipe pita variasi t'. Grafik rapat keadaan (b). graphene dengan $t=0 \mathrm{eV},(\mathrm{c}) \cdot t^{\prime}=0,1 \mathrm{t}$ (d). $t^{\prime}=0,5 \mathrm{t}$.

[8] S. Yuan, Hans De Raedt, Mikhail I. Katsnelson, Modeling electronic structure and transport properties of graphene with resonant scatteringcenters, PHYSICAL REVIEW B82, 115448, 2010.

[9] Balog, Richard., Bjarke Jørgensen, Louis Nilsson, Mie Andersen, Emile Rienks, Marco Bianchi, Mattia Fanetti, Erik Lægsgaard, Alessandro Baraldi, Silvano Lizzit, Zeljko Sljivancanin, Flemming Besenbacher, Bjørk Hammer,Thomas G. Pedersen, Philip Hofmann and Liv Hornekær, From graphene to graphane : A density functional investigation of metal insulator transition, arXiv:1003.6044v1, 2010. 